\title{
CONVERGENCE AND ECONOMIC GROWTH CONSIDERING HUMAN CAPITAL AND R\&D SPILLOVERS
}

\author{
Alejandro Diaz-Bautista* \\ Departamento de Estudios Económicos, El Colegio de la Frontera Norte \\ (Received 15 October 2002, accepted 15 April 2003)
}

\begin{abstract}
In the recent growth literature, the accumulation of human capital and R\&D have gained a central role. This study tries to narrow the bridge between the fields of regional convergence theory, economic growth and human capital. Unlike traditional economic growth theories, which tend to focus on exogenous comparative advantage or technological differences among regions as causes for growth, regional economic growth emphasizes the roles of increasing returns to scale in production, human capital and R\&D in determining the growth of economic activities. In particular, I will consider the interaction of regional human capital and R\&D economics following the recent work in economic growth and convergence. Using the recent developments in economic growth, the study centers on the regional convergence pattern in Mexico emphasizing the effects of human capital, R\&D and interregional spillovers on growth. The findings suggest the existence of some human capital and bounded knowledge spillovers across regional states in Mexico.
\end{abstract}

\section{Resumen}

En la literatura del crecimiento, la acumulación del capital humano y la investigación y desarrollo tienen un papel central. El estudio trata de cerrar la brecha entre el campo de la convergencia, el crecimiento económico y el capital humano. A diferencia de las teorías tradicionales del crecimiento, que se centran en las ventajas comparativas y las diferencias tecnológicas entre las regiones como los determinantes del crecimiento, las nuevas teorías del crecimiento regional enfatizan el papel de los retornos crecientes a escala en la producción, el capital humano y la investigación y desarrollo para determinar el crecimiento de las actividades económicas. En particular, el estudio considera la interacción entre el capital humano y la investigación y desarrollo en el ámbito regional, siguiendo los estudios recientes en el campo del crecimiento económico y la convergencia económica. El estudio se centra en el patrón de convergencia para México, al enfatizar los efectos del capital humano, la investigación y desarrolio y las derramas interregionales en el crecimiento. Los resultados sugieren que existen derrames en el capital humano pero restricciones en la actividad de investigación y desarrollo regional para los estados de México.

JEL classification: $04, J 24$

Keywords: Economic growth, Human capital

* Departamento de Estudios Económicos, El Colegio de la Frontera Norte, Abelardo L. Rodríguez 2925, Zona del Río. 22320. Tijuana, B. C., Teléfono: +52 (664)6313535, Correo Electrónico: adiazbau@hotmail.com

The author is very grateful to the anonymous referees for their comments. 


\section{Introducción}

At the end of the nineteen eighties, two influential papers by Romer (1986) and Lucas (1988), emphasizing knowledge led to a re-awakening of interest in determinants of economic growth. The breakthrough to studying technological change and growth was achieved by Romer (1990), building on the Grossman and Helpman (1989) modeling techniques. Important contributions in the growth literature were also made by Rebelo (1991), Grossman and Helpman (1991a, b, c) and Aghion and Howitt (1998). During the last decade, several models of economic growth tend to emphasize the importance of investment in intangible assets as a major source of economic growth. Investment in research and development (R\&D) and human capital has been ascribed to yield high social returns for the economy. Empirical studies have also confirmed the positive correlation between economic growth and educational or $R \& D$ expenditures at the macroeconomic level. Consequently, an important topic for Mexican economists who study the interaction of convergence and economic growth, is the interaction of R\&D and human capital in regional growth.

Endogenous growth theory and new trade theory created a new interest in regional economics and economic geography over the last decade. In the new regional economic perspective, internal regional conditions rather than external demand conditions are the most important growth stimulating factors. Economies of scalc exist in relation to capital, more specific in the production of human capital or knowledge and technology as in Romer (1986) and Krugman (1991). The marginal product of capital grows as the stock of capital expands. Put simply, the more we invest in knowledge the more the economy grows. In analyzing the strength of regions, Porter (1998) mentions that factor creation is related to social, cultural, historical and economic conditions in a specific national context. Demand impulses from the home market are important in the development of knowledge. A nationally well-developed functional division of labor is considered important in creating dynamic learning externalities and in utilizing economies of scale and scope (Porter 1998). Competitive strength is therefore developed in an interplay between factor conditions, demand conditions and the existence of related industries competing on an arena characterized by tough rivalry and continues improvements in all aspects of regional economic activities, including R\&D. Dynamic competition is therefore characterized both by regional rivalry and co-operation. Taking into account the arguments of externalities, transaction costs and dynamic competition, agglomerating forces are basically localization and urbanization externalities, which tend to lead to the regional clustering of economic activity. This may lead to a core-periphery pattern of regional economic growth and therefore $\beta$-divergence between the rich core states and less prosperous periphery regions. Alternatively, if labor remains relatively immobilc between regions, knowledge spillovers are high, and congestion costs are significant, then economic growth will induce spatial dispersal of economic activity and therefore $\beta$-convergence. The case studies of Silicon Valley by Saxenian (1994), Northern Italy by Storper (1992) and the Baden-Württemberg region in Germany by Sternberg (1999), are often cited to stress the importance of knowledge spillovers, which induces regional growth in core regions. For the Mexican case, we have several questions that are unanswered. What is the role of human capital and $R \& D$ in the regional growth process of Mexico? Does human capital support the transmission of knowledge 
and therefore promote future growth? The empirical work attempts to provide new insights on the regional pattern of the interaction of the Mexican states over the 1970-2000 period. The paper gives the literature review on human capital and R\&D models and regional growth studies. The empirical part of the study presents the data used in the human capital and R\&D model, the empirical methodology, and the empirical results given by the regression analysis. The final section gives some conclusions.

\section{A Review of Models and Studies}

Most economic theories have treated knowledge, either implicitly or explicitly, as an important factor in economic phenomena. The basic Solow (1956) model explains economic growth as a function of labor augmenting technological progress, population growth and the saving rate. It shows that the capital stock per effective unit of labor, $k$, converges towards a steady state $k^{*}$ at which actual investment is equal to break-even investment. Moreover, the neoclassical Solow model implies that the steady state income per capita, $(Y / L)$, depends positively on the saving rate and negatively on the population growth and depreciation rate. Although classical economists treated knowledge as a disturbance category in their model specifications, Marshall (1965) was among the first neoclassical economists to state explicitly the importance of knowledge in economic affairs. Marshall (1965) states that capital consists in a great part of knowledge and organization, as knowledge is our most powerful engine of production. In the eighties, the new endogenous growth theories were developed on the assumptions of imperfect competition between firms, the role of history, ideas and accidents, and the appearance of multiple equilibria in the markets. The existence of increasing returns for explaining sustained growth is supported and influenced by the research progress made in trade theory and industrial organization.

Romer (1986) defends the endogenous economic growth and increasing returns to scale view from location and knowledge accumulation perspectives. Some theoretical models of economic growth, such as Lucas (1988), Becker, Murphy and Tamura (1990), Rebelo (1991) ${ }^{1}$, Barro and Lee $(1993)^{2}$ and Mulligan and Sala-i-Martin (1992), emphasize the role of human capital in the form of educational attainment. Lucas's (1988) spillover model considers knowledge that is acquired through formal schooling and informal interaction with other people in the economy, where the individual investments in human capital do not take into account the spillover effect ${ }^{3}$. Lucas (1990) mentions that great

1 Rebelo (1991) presents a broad notion of capital. His suggestion is that accumulating both human and physical capital together ensures no diminishing returns to capital as a group. Using $Y=A K^{\alpha}(h L)^{1-\alpha}=A K^{\alpha} h^{1-\alpha} L^{1-\alpha}$ as the production function, suggests that increases in both forms of capital at the same rate ensures constant returns to both, and increasing returns to the accumulation of all three inputs. The model reduces to an $A K$ type model where $K$ includes human capital.

2 Barro and Lee(1993), constructed estimates of educational attainment by sex for persons aged 25 and over. The values applied to 129 countries over a five year intervals from 1960 to 1985.

3 The spillover effect eliminates diminishing returns to human capital accumulation and al- 
differences in per capita income are mainly explained by differences in human capital per capita, including cultural traits and skills of people in different regions. The average level of human capital in the form of occupational skills or education in a society can obviously influence the level of per capita income in the economy. Romer (1990) assumes a Solow type production function $Y=K^{\alpha}\left(A L_{y}\right)^{1-\alpha}$ where $A$ is the stock of ideas invented and $\Delta A$ the number of ideas generated at a point in time, which depends on the number of researchers and their productivity as well as the current stock of ideas. The productivity of researchers is a decreasing function of the total number of researchers as there is greater duplication of research effort (wasted resources for society). ${ }^{4}$

Recent research in the economic growth literature, such as Barro and Salai-Martin (1991) focused on the convergence of regional income in developed economies. They address the question of whether poor regions tend to converge toward rich ones. For the U.S. states, they estimate the rate of convergence of per capita personal income from 1880 to 1988 to be around 2 percent per year by looking within or across four geographical regions. They also find a rate of convergence of about 2 percent per year for per capita GDP across 73 regions of seven European countries from 1950 to 1985. They concentrate in factors that lead either to convergence or divergence, but the factors that may explain one, may not explain the other. Another explanation of regional convergence and divergence could be given by technological diffusion, and R\&D. Barro and Sala-i -Martin (1995), construct an endogenous growth model that includes the convergence of the neoclassical growth model. They argue that in the long run, the world growth rate is driven by discoveries and ideas in the technologically leading countries. Followers converge toward the leaders because copying is cheaper than innovation over some range.

The new economic geography and most endogenous growth models recognize the concept of capital accumulation, knowledge and research spillovers in determining the location and growth of core regions. The regional model could combine imperfect competition with human capital, innovation-based growth and learning-by-doing in innovation. These forces generate intraregional and

lows this to drive long-run growth. The production function is defined as $Y=K^{\alpha}(h L)^{1-\alpha}$ where $K$ and $L$ are capital and labor, $h$ is human capital and $\Delta h / h=(1-\mu)$, with $\mu$ being the proportion of time allocated to accumulating human capital due to no diminishing returns to human capital. In the model human capital $(h)$ has the same role as $A$ in the Solow model. In the model there are possible virtuous cycles and poverty traps, where high levels of schooling creates more knowledge from spillovers which increases the incentive for individuals to invest in schooling.

4 The relationship to the stock of ideas depends on the balance of forces that can raise productivity by being a foundation for research or can lower it by eliminating all the easy ideas. The number of ideas $A=\delta L_{A}^{\lambda} A^{\phi}$, depends on the assumption of $\lambda$ and $\phi$. With $\lambda=1$ (no duplication effect) and $\phi=1$ (productivity of research grows with stock of ideas) then $\Delta A=\delta L_{A} A$ and $\triangle A / A=\delta L_{A}$. Economic growth occurs under a constant research effort proportional to the amount of researchers in the economy. The results are similar to the Solow model, where growth in technology drives economic growth, but in this model it occurs through skill accumulation and the technology transfer process. The differences in per capita income levels are determined by differences in the time spent accumulating skills. 
interregional spillovers from a high level of human capital and R\&D. Aghion and Howitt (1998) derive a model that is driven by product differentiation, quality improvements and research spillovers. Bottazzi and Peri (1999) consider a model with $N$ regions in the spirit of the endogenous growth literature where skilled workers are perfectly mobile both between research and production and across regions. Each region innovates by adding further intermediate goods that increase the productivity and technological level of the region itself. Finally they allow for spillovers in the level of knowledge across regions. In particular, there exists a catch-up process, which prevents an individual region per capita income level to grow increasingly apart from other regions or a diffusion of knowledge across space, which binds regions together.

Kelly and Hageman (1999) construct a quality ladder model of growth augmented by Marshallian externalities that are more important for innovation than for production. An important feature is that innovation and production need not occur in the same locations. R\&D activities and a large level of regional human capital can have an important effect on growth irrespective of the location. Audretsch (1998) and Krugman (1998) mention that there could be geographical boundaries to $\mathrm{R} \& \mathrm{D}$ spillovers, particularly because of tacit knowledge.

For Mexico, there have been some advances in terms of education and R\&D. Between 1970 and 1995; the illiterate population below 15 years of age diminished from 26 to 11 percent in Mexico. However, the human capital indicators for Mexico show a low level of matriculation in the elementary and high school age groups compared to other countries, as well as a low number of researchers per million inhabitants, which are shown in the next table.

Źlkiewski (1999), has mentioned that the XXI Century will be the century of economy based on knowledge, where expenditures for future development of scientists and researchers which includes expenditure on $R \& D$ and expenditure on education will drive economic growth.

When making international comparisons of R\&D activities, Mexico ranks among the lowest in OECD countries. In terms of gross domestic expenditures on R\&D, Mexico ranks as one of the last countries within OECD in terms of the ratio of domestic expenditures on R\&D activity to GDP and in terms of expenditures per capita. These observations give rise to the question as to the degree to which R\&D activities are promoted in Mexico. The use of the R\&D expenditures as an indicator for the technological development has received two kinds of criticisms. On the one hand, it has been claimed that R\& D spending is an overstated measure of the efforts in technological activities in view of the high rates of failures that are likely to occur in $R \& D$ projects. On the other hand, others have argued its understatement, because it does not include the payments for imports of technology. Another way to measure the technological development and research in a country is by the number of researchers in the country. The average level of human capital in the form of occupational skills or education and the number of researchers in a society can obviously influence the level of its per capita income. This is why it is important to study the influence of R\&D activity and the level of human capital in the promotion of regional economic growth in Mexico. 
Table 1: Education in Mexico, 2000.

\begin{tabular}{|c|c|}
\hline Cost by primary and secondary student as (\% of the GDP per capita) \\
\hline $\begin{array}{c}11 \text { and } 16 \\
\text { Mexico } \\
\text { OECD Countries }\end{array}$ \\
\hline \multicolumn{2}{|c|}{ Coverage of university education (\%) 24} \\
\hline Mexico & 21 \\
Argentina, Chile and Uruguay & 28 \\
\hline Average of students by classroom in basic education \\
\hline Mexico & 27.2 \\
OECD Countries & 18 \\
\hline Elementary, Junior High, baccalaureate Matriculation (\%) \\
\hline Mexico & 71 \\
Colombia & 73 \\
Panama & 74 \\
Uruguay & 79 \\
Peru and Brazil & 80 \\
\hline Researchers per million inhabitants \\
\hline Japan & 5,130 \\
Mexico & 97 \\
\hline
\end{tabular}

Sources: Secretaría de Educación Pública (2000) and OECD (2000).

\section{The Model of Economic Growth, Human Capital and R\&D Spill- overs}

Mankiw, Romer and Weil (1992) have shown that growth differences across the world are surprisingly consistent with the Solow model, when augmenting with human capital. Coe and Helpman (1995) and Bayoumi et al. (1999) have found that both R\&D and human capital contribute significantly to total economic growth. Moreover, R\&D has become increasingly important, especially for smaller countries. Econometric studies for the United States and Europe using aggregate and micro level data have also underlined the importance of regional specialized knowledge. Feldman (1994) and Audretsch and Feldman (1996) derive a model of knowledge production function to include an explicit specification for the regional dimension. Brandstetter (1996) has estimated the size of intranational spillovers that usually exceed international spillovers using microlevel data. The international evidence tends to confirm the existence of intraregional human capital and R\&D spillovers in the growth process. In this study, the basic model of human capital, R\&D spillovers and regional economic growth is based on Romer's (1996) endogenous model of technological change and Aghion and Howitt (1998) growth model. The model starts with the simple aggregate production function in region $i$ that is given by the following equation:

$$
Y_{i}=K^{\chi} H^{\alpha}\left(L_{Y}\right)^{1-\alpha} H^{\beta}\left(L_{A}^{1-\beta}\right),
$$


Table 2. Gross Domestic Expenditures on R\&D as \% of GDP (1994-1999).

\begin{tabular}{|c|c|c|c|c|c|}
\hline & \multicolumn{2}{|c|}{ as \% of GDP } & & \multicolumn{2}{|c|}{ USD per capita (current PPP) } \\
\hline Countries & 1994 & 1999 & Countries & 1994 & 1999 \\
\hline Sweden & $3.27^{c)}$ & $3.70^{b)}$ & USA & 650.3 & 892.5 \\
\hline Finland & 2.29 & 3.09 & Sweden & $571.6^{c)}$ & $773.8^{b)}$ \\
\hline Japan & 2.84 & $3.04^{a)}$ & Japan & 602.5 & $732.6^{a)}$ \\
\hline USA & 2.42 & 2.65 & Finland & 381.9 & 707.1 \\
\hline Korea & 2.44 & $2.55^{a)}$ & Germany & 454.8 & 563.0 \\
\hline Germany & 2.26 & 2.38 & Denmark & $344.5^{c)}$ & 520.6 \\
\hline France & 2.34 & $2.18^{a)}$ & Iceland & 270.6 & 495.7 \\
\hline Denmark & $1.74^{c)}$ & 1.99 & Norway & $370.4^{c)}$ & 480.9 \\
\hline Netherlands & $\left.2.00^{c}\right)$ & $1.95^{a)}$ & Netherlands & 382.3 & $470.8^{a)}$ \\
\hline Iceland & 1.38 & 1.88 & France & 446.8 & $461.6^{a)}$ \\
\hline Belgium & 1.74 & $1.84^{b)}$ & Austria & 312.8 & 450.7 \\
\hline United Kingdom & 2.07 & $1.83^{a)}$ & Belgium & 360.3 & $419.5^{b)}$ \\
\hline Austria & 1.53 & 1.82 & Canada & 348.2 & 419.0 \\
\hline Norway & 1.73 & 1.73 & United Kingdom & 372.7 & $395.8^{a)}$ \\
\hline Canada & 1.67 & 1.58 & Когеа & 286.1 & $365.7^{a)}$ \\
\hline Australia & 1.61 & $1.49^{a)}$ & Australia & 312.9 & 360.9 \\
\hline
\end{tabular}

a) 1998 b) 1997 c) 1993 d) 1995 e) 1996

Source: Main Science and Technology Indicators, OECD. 
Table 2. Gross Domestic Expenditures on R\&D as \% of GDP (1994-1999). (continue)

\begin{tabular}{|c|c|c|c|c|c|}
\hline & \multicolumn{2}{|c|}{ as $\%$ of GDP } & & \multicolumn{2}{|c|}{ USD per capita (current PPP) } \\
\hline Countries & 1994 & 1999 & Countries & 1994 & 1999 \\
\hline Ireland & 1.31 & $1.39^{b)}$ & Ireland & 209.2 & $296.1^{b)}$ \\
\hline Czech Republice $^{e)}$ & 1.10 & 1.27 & Italy & 198.3 & 231.0 \\
\hline New Zealand & $1.02^{c)}$ & $1.13^{b)}$ & New Zealand & $153.0^{c)}$ & $199.4^{b)}$ \\
\hline Italy & 1.05 & 1.04 & Czech Republice $^{e)}$ & 120.9 & 167.4 \\
\hline Spain & 0.85 & 0.90 & Spain & 115.5 & 163.5 \\
\hline Poland & 0.78 & 0.75 & Portugal & $78.1^{d)}$ & $95.2^{b)}$ \\
\hline Hungary & 0.89 & 0.68 & Hungary & 74.0 & 75.9 \\
\hline Portugal & $0.57^{d)}$ & $0.62^{b)}$ & Greece & $52.5^{c)}$ & $68.7^{b)}$ \\
\hline Greece & $0.48^{c)}$ & $0.51^{b)}$ & Poland & 44.6 & 63.6 \\
\hline Turkey & 0.36 & $\left.0.49^{b}\right)$ & Turkey & 19.1 & $31.3^{b)}$ \\
\hline Mexico & 0.29 & $0.34^{b)}$ & Mexico & 20.5 & $26.0^{b)}$ \\
\hline Switzerland & $2.73^{e)}$ & & Switzerland & $685.1^{e)}$ & \\
\hline European Union & 1.84 & $1.81^{a)}$ & European Union & 339.9 & $385.1^{a)}$ \\
\hline OECD & 2.10 & $2.18^{a)}$ & OECD & 399.7 & $469.4^{a)}$ \\
\hline
\end{tabular}

a) 1998 b) 1997 c) 1993 d) 1995 e) 1996

Source: Main Science and Technology Indicators, OECD. 
where $K$ is capital and $H(L)$ is the state specific human capital stock (regional raw labor force) or the amount of human capital (raw labor) available in all regions, and $0<\alpha, \chi<1$, and $\beta>0$. The regional raw labor force is used to produce either output or ideas $\left(L=L_{Y}+L_{A}\right)$, where $L_{Y}$ is the labor used to produce output and $L_{A}$ is the labor used to produce ideas. The production process is assumed to generate positive knowledge externalities.

Consider the effects of human capital in the model, in the case where there is no physical capital. The higher the average level of human capital in the economy, the greater the incidence of knowledge spillovers to raise the marginal productivity of human capital across regions. In other words, the external human capital produces a public good effect that adds to the region-specific stocks of $L$ and $H$. Human capital in region $i$ is paid its private marginal product $(M P H)$, thus

$$
M P H=\alpha\left(H_{i} / L_{i}\right)^{\alpha-1}(H / L)^{\beta} .
$$

In equilibrium, $H_{i} / L_{i}=H / L$, so the marginal product of human capital can be rewritten as

$$
M P H=\alpha(H / L)^{-(1-\alpha-\beta)} .
$$

The regional aggregate production function can be written by substituting (3) in (1) as:

$$
Y=H^{(\alpha+\beta)} L^{(1-\alpha-\beta)} .
$$

Defining regional production it per capita as $y \equiv Y / L$ and regional production per capita as $h \equiv H / L$, allows us to define the regional production function in intensive form given by

$$
y=h^{\alpha+\beta} .
$$

Taking the time derivatives of both sides of $h$ yields the following equation:

$$
\dot{h}=s h^{\alpha+\beta}-n h .
$$

The equation gives the standard result of the Solow model, where $s$ is the level of savings in the economy. The economy will converge to a situation where actual investment per capita is equal to break-even human capital investment per capita. The steady state human capital stock $h^{*}$ is then given by

$$
h^{*}=\left(\frac{s}{n}\right)^{\frac{1}{1-\alpha-\beta}}
$$

The steady state per capita human capital stock $h^{*}$ is an increasing function of $\beta$ and therefore the size of the regional spillover effects. The regional spillover externality implies that, absent government intervention, private $y_{i} *=f\left(h_{i} *\right)$ will be suboptimally low because individual regions do not internalize the learning by doing externalities that their investment produces for other regions.

The question of whether human capital and regional knowledge externalities are present in Mexico is answered in the next section. Using data for the 
states of Mexico, the empirical convergence analysis links regional per capita GDP growth, human capital levels and R\&D activity.

\section{The Empirical Analysis}

In this paper, the analysis is focused on the regional interaction and convergence of human capital and R\&D. The identification of the regional interaction structure is based on a generalized growth regression analysis that focuses on the relationship between regional income per capita growth and the human capital and $R \& D$ activity. The dependent variable is the average annual income per capita growth rate between 1970 and 2000 obtained from INEGI. To test the convergence hypothesis of income per capita and to estimate the annual velocity of convergence, the following non lineal model is derived from the aggregate production function

$$
\begin{aligned}
& (1 / T) \operatorname{Ln}\left(Y_{i, t+T} / Y_{i t}\right)=\alpha-\left(\operatorname{Ln}\left(Y_{i t}\right)\right)\left(1-e^{-\mu t}\right)(1 / T)+ \\
& \text { educational variables }+R \& D \text { variable }+U_{i t} .
\end{aligned}
$$

where $Y_{i t}$ is the level of income per capita in region $i, t$ is the initial time, $T$ is a period of time, $\mu$ is the velocity of convergence or the average annual rate at which economies get closer to the steady state.

The higher the $\mu$, the lower the period of time necessary for the system to reach the long run equilibrium. If $\mu<1$ the system diverges. The initial regional income per capita is considered as an additional explanatory variable in the regressions in order to test for conditional $\beta$-convergence because in a semiendogenous growth setting the conditional convergence through technological diffusion will be reinforced by the familiar Solow-like conditional convergence. $U i$ is an error term for region $i$. The error terms will be assumed to be iid. with zero mean and variance $\sigma^{2}$. The best procedure for estimating the stock of human capital is the one followed in Barro and Lee (1996), by approaching the human stock of a country in terms of the level of education of its working age population according to the years of schooling at all levels of education. This is, therefore, the method followed here. 'The data on education used in the present study comes from the Secretaría de Educación Pública (2000), INEGI and the Ministry of Education website. The educational variables used to condition the data are the following:

Illiterate refers to the percentage of people that know how to read and write. Elementary is a variable that show the percentage of people with elementary studies completed.

Some Junior High is a variable that refers to the percentage of people that have more that elementary studies, but haven't finished junior high.

Finished Junior High refers to the percentage of people that completed a level of education in the National Educational System.

High School refers to the percentage of people that completed a level of education in the National Educational System.

College refers to the percentage of people that are in college or completed a level of education in University studies. 
$R \& D$ activity is measured by the number of Researchers per state at the SNI (Sistema Nacional de Investigadores) in the year 2000 provided by CONACYT.

The econometric results are shown in the following table. The results are based generalized least squared regressions with and without $R \& D$ activity and by level of human capital. For the period 1970 to 1993 , the conditional convergence $\mu$ parameter is the $1.4 \%$ positive and significant, while for the period 1970 to 2000 the parameter is close to $3.2 \%$ without considering the $R \& D$ activit. The results indicate that the states of Mexico can reach a level of long run income. For the period 1985-1993, the convergence parameter is negative $1.4 \%$, but not significant indicating that states of Mexico were diverging in this short period from the long run level in income per capita.

The results indicate that the proposed method can serve as a guideline for regional convergence and growth specifications in Mexico. The results depend on the structure of regional human capital and R\&D activity. In other words, it depends on the assumed geographical extent of R\&D activity in Mexico. Only for the regression with the $\mathrm{R} \& \mathrm{D}$, no regional significance of human capital can be detected. The result seems to be generated by the concentration of $R \& D$ in the Mexico City area, where more than $50 \%$ of all R\&D activity is concentrated.

For the period 1970-1993 the half-life was 50.4 years. This is the number of years to cover half the distance of the logarithms of income per capita. However, the regressions yields non-significant coefficient for all explanatory variables, except for the convergence coefficient. The convergence coefficient confirms the findings of previous studies on conditional $\beta$-convergence done in Mexico, which include Esquivel (1999), Díaz-Bautista (2000) and Messmacher (2000).

The empirical analysis provides empirical evidence for the hypothesis that $R \& D$ spillovers are regionally bounded and do not constitute a significant source of regional economic growth. The huge agglomeration in Mexico City can be assessed as the main origin of the non-existent R\&D spillovers at a regional scale in Mexico. As for human capital, elementary education is starting to be an important factor that explains regional economic convergence in Mexico due to the similar coverage at the state level.

\section{Conclusions}

In this paper, we have investigated the role of human capital accumulation and R\&D in explaining growth paths across the Mexican states over the 1970 2000 period. Moreover, the human-capital-augmented growth equation was estimated using a consistent generalized least squares econometric technique that allows for the speed of convergence as well as for the short-term dynamics and variances to vary across regions. An important finding in the paper is that of $\dot{\beta}$-convergence for the Mexican states when augmented with human capital and $R \& D$. The regions in Mexico that are initially far below their steady states grow faster than the regions that are close to their steady states. 
Table 3. Estimated Results of the Velocity of Convergence in Income per capita. Conditional to $R \& D$ and Human Capital Variables in Mexico

\begin{tabular}{|c|c|c|c|c|c|c|}
\hline \multicolumn{2}{|c|}{ Dependent Variable: Average Annual Income Per Capita Growth Rate } \\
\hline Period & $1970-1993$ & $1970-1985$ & $1970-1980$ & $1970-2000$ & $1985-1993$ & $1970-2000$ \\
\hline$\alpha$ & -0.008 & 0.031 & 0.046 & -0.023 & -0.010 & 15.98 \\
& $(-0.6671)$ & $(2.0441)$ & $(1.9122)$ & $(0.405)$ & $(-.1548)$ & $(1.98)$ \\
\hline$\mu$ & $0.014^{*}$ & $0.031^{*}$ & 0.018 & $0.032^{*}$ & -0.014 & $0.45^{*}$ \\
& $(1.628)$ & $(2.6696)$ & $(1.2769)$ & $(2.546)$ & $(-0.619)$ & $(2.38)$ \\
\hline Elementary & .10572 & 0.026328 & -0.08076 & $0.017^{*}$ & -0.8378 & 0.150 \\
& $(.04575)$ & $(0.0545)$ & $(0.0886)$ & $(2.26)$ & $(0.1759)$ & $(1.78)$ \\
\hline Some Junior High & -0.36605 & -0.176821 & -0.199977 & 0.0015 & 0.1792 & -0.149 \\
& $(.15247)$ & $(.18183)$ & $(.29560)$ & $(0.141)$ & $(0.3266)$ & $(1.78)$ \\
\hline Finished Junior High & 6.01545 & 2.43713 & 5.120347 & 0.0028 & -0.4447 & 0.162 \\
High & $(1.8517)$ & $(2.1678)$ & $(3.5241)$ & $(0.186)$ & $(0.7874)$ & $(1.98)$ \\
\hline
\end{tabular}

*Significance at $5 \%$ level. $\mathrm{T}$ stats in parenthesis. 
Table 3. Estimated Results of the Velocity of Convergence in Income per capita. Conditional to $R \& D D$ and Human Capital Variables in Mexico (continue)

\begin{tabular}{|c|c|c|c|c|c|c|}
\hline \multicolumn{2}{|c|}{ Dependent Variable: Average Annual Income Per Capita Growth Rate } \\
\hline Period & $1970-1993$ & $1970-1985$ & $1970-1980$ & $1970-2000$ & $1985-1993$ & $1970-2000$ \\
\hline High School & 1.8517 & 0.704419 & 0.860725 & 0.006 & 0.11467 & 0.145 \\
& $(.56078)$ & $(0.6687)$ & $(1.0871)$ & $(0.372)$ & $(0.4351)$ & $(1.98)$ \\
\hline College & -0.79644 & -0.187491 & -0.456506 & 0.225 & -0.2228 & 0.147 \\
& $(0.3394)$ & $(0.4048)$ & $(0.6581)$ & $(1.495)$ & $(0.4026)$ & $(1.71)$ \\
\hline Illiterate & 0.017202 & -0.002294 & 0.012342 & 0.003 & 0.00067 & 0.161 \\
& $(0.0098)$ & $(0.0117)$ & $(0.0191)$ & $(0.365)$ & $(0.0056)$ & $(1.962)$ \\
\hline R\&D Activity & & & & & & 0.003 \\
& & & & & & $(1.29)$ \\
\hline Half life & 50.4 & 22 & 37.8 & 31.7 & 49.8 & 32.5 \\
\hline$R^{2}$ adjusted & 0.401 & 0.440 & 0.221 & 0.072 & 0.068 & 0.320 \\
\hline T (years) & 23 & 15 & 10 & 30 & 8 & 30 \\
\hline
\end{tabular}

*Significance at $5 \%$ level. T stats in parenthesis. 
In the study we tried to control for the steady state of a regional economy by adding extra explanatory variables such as the level of human capital and $\mathrm{R} \& \mathrm{D}$, which have been interpreted in the literature as potential determinants of a region's steady state.

Barro and Sala-i-Martin (1995) have tried to show that conditional convergence is a universally relevant phenomenon, and that the rate of this convergence is surprisingly stable: around $2 \%$ per year. While the basic objective of Mankiw, Romer and Weil (1992) is to show that the growth differences across the world are surprisingly consistent with the Solow model, augmented with human capital. The interesting results seem to be that basic human capital is important in determining the level of convergence in the states of Mexico in accord with Mankiw, Romer and Weil (1992), with rates of convergence far higher than previously anticipated. It is in this sense that educational policies oriented to permit an increased regional growth of the less developed regions in the regional integration process becomes very important.

The building up of a regional integration process should be considered by the Mexican Government in order to bring economic growth to all of the regions involved not leaving some regions aside. The results also confirm the empirical evidence on bounded non-existent knowledge spillovers, shown by the increased concentration of R\& D activities in Mexico City. In other words, the findings suggest that regional growth is not determined by regional R\&D activity, due to the lack of expenditures on R\&D at the national and regional level, and to the increase concentration of R\&D in the Mexico City Metropolitan Area. Thus, the paper confirms the qualitative hypothesis that R\&D knowledge and human capital may spill over, but the regional extent of such knowledge spillovers may be bounded in Mexico.

\section{References}

Aghion, P., and Howitt, P. (1998). Endogenous Growth Theory, Cambridge/Mass. (MIT Press).

Audretsch, D. (1998). Agglomeration and the Location of Economic Activity. Oxford Review of Economic Policy, 14, 18-29.

Audretsch, D., and M. Feldman (1996). R\&D Spillovers and the Geography of Innovation and Production. American Economic Review, 86, 630-640.

Auerbach, A. J., Hassett, K.A., and S. D. Oliner (1994). Reassessing the Social Returns to Equipment Investment. Quarterly Journal of Economics, 109, 789-802.

Bade, F. J., and A. Niebuhr (1998). Zur Stabilitat des Räumlichen Strukturwandels. Jahrbuch für Regionalwissenschaft, 19, 131-156.

Barro, R., and J. W. Lee (1996). International Measures of Schooling years and Schooling Quality. American Economic Review, Papers and Proceedings, Vol. 86, No. 2, pp. 218-223.

Barro, R., and X. Sala-i-Martin. (1991). Convergence across States and Regions. Brookings Papers on Economic Activity, 1, pp. 107-58.

Barro, R., and X. Sala-i-Martin (1992). Journal of Political Economy, 100(2), pp. 223- 51.

Barro, R., and X. Sala-i-Martin (1995). Economic Growth. 1st ed., New York (McGrawHill).

Barro, R., and X. Sala-i-Martin (1995). Technological Diffusion, Convergence, and Growth. NBER Working Paper No. 5151, June 1995.

Barro, R., and X. Sala-i-Martin. (1996), Regional Cohesion: Evidence and Theories of Regional Growth and Convergence. European Economic Review, June, 1996. 
Bayoumi, T., Coe, D., and E. Helpman (1999). R\&D Spillovers and Global Growth. Journal of International Economics, 47, 399-428.

Becker, G., K. Murphy, and H. Tamura (1990). Human Capital, Fertility, and Economic Growth. Journal of Political Economy, 98, s12-s37.

Blomström, M., R. Lipsey, and M. Zejan (1996). Is Fixed Investment the Key to Economic Growth?, Quarterly Journal of Economics, 111, pp. 269-276.

Bode, E. (1998). Lokale Wissensdiffusion und Regionale Divergenz in Deutschland, Tübingen.

Brakman, S., H. Garretsen, and M. Schramm (2000). The Empirical Relevance of the New Economic Geography: Testing for a Spatial Wage Structure, CESifo Discussion Paper No. 395, München.

Branstetter, L. (1996). Are Knowledge Spillovers International or Intranational in Scope? Microeconometric Evidence from the U.S. and Japan, NBER Working Paper No. 5800, Cambridge.

Bode, E. (1999a). Localized Knowledge Spillovers and Regional Employment Growth: Evidence from Germany. The Kiel Institute of World Economics, Working Paper No. 938, Kiel.

Bode, E. (1999b). R\&D, Localized Knowledge Spillovers, Endogenous Regional Growth: Evidence from Germany, Kiel, mimeo.

Bottazzi, L., and G. Peri (1999). Innovation, Demand and Knowledge Spillovers: Theory and Evidence from European Regions, CEPR Discussion Paper No. 2279, London.

Coe, D.T., and E. Helpman (1995). International R\&D Spillovers. European Economic Review, 39, pp. 859-887.

CONACYT (2000). Actividades Científicas y Tecnológicas. Pagina electrónica del CONACYT.

Díaz-Bautista, A. (2000). Convergence and Economic Growth in Mexico. Frontera Norte, 13, pp. 85-110, julio-diciembre de 2000.

Díaz-Bautista, A. (2001). An Introduction to Institutional Change, Corruption and Economic Growth, Cuaderno de Trabajo, DTE 35/01, Departamento de Estudios Económicos, El Colegio de la Frontera Norte, México.

Dixit, A., and J. Stiglitz (1977). Monopolistic competition and optimal product diversity. American Economic Review, 67 pp. 297-308.

Englmann, F., and U. Walz (1995). Industrial Centers and Regional Growth in the Presence of Local Inputs and Knowledge Spillovers, Journal of Regional Science 35, pp. 3-27.

Esquivel, G. (1999). Convergencia Regional en México. El Trimestre Económico, 67, Octubre-Diciembre, México.

Feldman, M. (1994). The Geography of Innovation, Dordrecht (Kluwer Academic Publishers).

Grossman, G., and E. Helpman (1989). Product Development and International Trade. Journal of Political Economy, (97) pp. 1261-1283.

Grossman, G., and E. Helpman (1991a). Innovation and Growth in the Global Economy. Cambridge, Massachusetts, MIT Press.

Grossman, G., and E. Helpman (1991b). Endogenous Product Cycles. The Economic Journal, 101, pp. 1214-1229.

Grossman, G., and E. Helpman (1991c). Quality Ladders in the Theory of Growth. Review of Economic Studies, 58 pp. 43-61.

Grossman, G., and E. Helpman (1994). Endogenous Innovation in the Theory of Growth. Journal of Economic Perspectives, 8, pp 23-44.

Hanson, G. (1994). Regional Adjustment to Trade Liberalization. Working Paper No. 4713, NBER.

INEGI. VIII, IX, X, XI Censo General de Población y Vivienda. Instituto Nacional de Estadística, Geografía e Informática, (INEGI), México. 1960, 1970, 1980, 1990, 2000 y pagina electrónica.

Jaffe, A., M. Trajtenberg, and R. Henderson (1993). Geographic Localization of Knowledge Spillovers as Evidenced by Patent Citations, Quarterly Journal of Economics, 63, pp. 577-598. 
Jones, C. (1995). R\&D-Based Models of Economic Growth, Journal of Political Economy, 103, pp. 759-784.

Keller, W. (1998). Are International R\&D Spillovers Trade-Related? Analyzing Spillovers Among Randomly Matched Trade Partners. European Economic Review, 42, pp. 14691481.

Kelly, M, and A. Hageman (1999). Marshallian Externalities in Innovation. Jourmal of Economic Growth 4, pp. 39-54.

Krugman, P. (1991). Increasing Returns and Economic Geography. Journal of Political Economy, 99(3) pp. 483-499.

Krugman P, and A. Venables (1995). Globalization and Inequality. Quarterly Journal of Economics, 110 , pp. 857-880.

Krugman, P. (1998). Whats New About the New Economic Geography? Oxford Review of Economic Policy, 14, pp. 7-17.

Livas Elisondo, R. (1992). Trade Policy and the Third World Metropolis, NBER Working Paper No. 4238, December 1992.

Lucas, R. (1988). On the Mechanics of Economic Development. Journal of Monetary Economics, 22 , pp. 3-42.

Lucas, R. (1990). Why Doesn't Capital Flow from Rich to Poor Countries?, American Economic Review Papers and Proceedings, 80(2) pp. 92-96.

Mankiw, G., D. Romer, and D. Weil (1992). A Contribution to the Empirics of Economic Growth, Quarterly Journal of Economics, 107, 152(2) (May) pp. 407-437.

Marshall, A. (1965). Principles of Economics. London: Macmillan.

Messmacher, M. (2000). Desigualdad Regional en México. El Efecto del TLCAN y otras Reformas Estructurales. Documento de Investigación No.2000-4, Dirección General de Investigación Económica, Banco de México, Diciembre, pp. 1 - 33.

Mulligan, C. and X. Sala-I-Martin (1992). Two capital goods models of Economic Growth. Unpublished paper ( Yale University, New Haven, CT).

Myrdal, G. (1957). Economic Theory and Underdeveloped Regions, London: Gerald Duckworth.

OECD (1994). The Measurement of Scientific and Technological Activities. Proposed Standard Practice for Surveys of Research and Experimental Development. FRASCATI Manual 1993, OECD, Paris.

OECD (2000). Main Science and Technology Indicators, Nr. 2, OECD, Paris.

Porter, M. (1998). Clusters and the New Economics of Competition. Harvard Business Review, November-December 1998.

Porter, M. (1998b). The Adam Smith address: Location, Clusters, and the new Microeconomics of Competition. Business Economics, 33(1), 7-13.

Rebelo, S. (1991). Long-Run Policy Analysis and Long-Run Growth. Journal of Political Economy, 99 pp. 500-521.

Romer, P. (1986). Increasing Returns and Long-Run Growth, Journal of Political Economy, 94, pp. $1002-1037$.

Romer, P. (1990). Endogenous Technological Change, Journal of Political Economy, 98, S71-S102.

Romer, P. (1994). The Origins of Endogenous Growth, Journal of Economic Perspectives, 8(1), pp. 3-22.

Romer, D. (1996). Advanced Macroeconomics, New York (McGraw-Hill).

Sala-I-Martin, X. (1997). I Just Ran two Million Regressions, American Economic Association Papers and Proceedings, May.

Saxenian, A. (1994). Regional Networks: Industrial Adaption in silicon Valley and Route 128, Cambridge/Mass. (Harvard University Press).

Secretaría de Educación Pública (2000). Estadísticas Educativas y Secretaría de Educación Pública (SEP) Website: http://www.sep.gob.mx.

Solow, R. (1956). A Contribution to the Theory of Economic Growth, Quarterly Journal of Economics, February, pp. 65-94. 
Solow, R. (1957). Technical Change and the Aggregate Production Function, Review of Economics and Statistics, 39, pp. 312-320.

Sternberg, R. (1999). Innovative Linkages and Proximity: Empirical Results from Recent Surveys of Small and Medium-Sized Firms in German Regions, Regional Studies, 33, pp. 529-540.

Stetzer, F. (1982). Specifying Weights in Spatial forecasting Models: The Results of Some Experiments. Environment and Planning, 14, pp. 571-584.

Storper, M. (1992). Regional "Worlds" of Production: Learning and Innovation in the Technology Districts of France, Italy and the USA. Regional Studies, 27, pp. 433-455.

Sturm, J., and J. de Haan (2000). No Need to Run Millions of Regressions, CESifo Working Paper No. 288, München.

Talen, E., and L. Anselin (1998). Assessing Spatial Equity: An Evaluation of Measures of Accessibility to Public Playgrounds, Environment and Planing, 30, pp. 595-613.

Varga, A. (1998). Local Academic Knowledge Spillovers and the Concentration of Economic Acitivity, Regional Research Institute, West Virginia University, Research Paper No. 9803, Morgantown.

Young, A. (1998). Growth without Scale Effects, Journal of Political Economy, 106, pp. 41-63.

Zólkiewski, Z. (1999). R\&D in Poland, 1994- 997: A satellite account perspective, Research Bulletin, Vol. 8, 1999, No 3-4. 